\title{
METODE HOMESCHOOLING, MODEL ALTERNATIF PENDIDIKAN ANAK USIA DINI DI MASYARAKAT
}

\author{
Ida Bagus Nyoman Wartha \\ Program Studi Pendidikan Sejarah, Fakultas Keguruan dan Ilmu Pendidikan \\ Universitas Mahasaraswati Denpasar
}

\begin{abstract}
Learning is necessity, not just for children, but also for all people required to get an education. Bresekamp, an expert on developmental psychology (1997:97), reveals that administration in early children education is recognized as a very important period in building human resources and the danger comes once this period and can not be repeated again, so that stimulation can be started with an education that can be absolutely necessary.

Homeschooling is a process that can be done by any parents who love and care their children. Any educational background or job does not preclude parents to make educational homeschooling. It needs commitment, willingness to learn, and work hard. Homeschooling is not an easy thing, but it can be carried out because it has millions of parents who do it for their children

Homeschooling families who apply this system, must see that this model has a great opportunity to teach the habit of looking for any information for their children's education needs which focus on skills that are loaded with the latest information.

Homeschooling can be an alternative method for children's education in the early age, in addition to its application implemented in home environment, kids can directly interact and apply their knowledge in the real world, and at the same time, the children can immediately get explanation or correction when making the mistake.

In addition to be able to carry out the methods of homeschooling, parents should be able to spend their time for their children and be creative and innovative so as to be able to attract and interact in knowing the curiosity of the children.
\end{abstract}

Key words: homeschooling, education of children, parents.

\section{PENDAHULUAN}

Knowledge is power, kutipan yang terkenal dari Prancis Bacon tersebut jelas mengungkapkan pentingnya pendidikan bagi manusia. Sumber pokok kekuatan manusia adalah pengetahuan. Mengapa ?, karena manusia dengan pengetahuannya dapat melakukan olah cipta sehingga ia mampu bertahan dalam masa yang terus maju dan berkembang. Dan proses olah cipta tersebut terlaksana berkat adanya sebuah aktivitas yang dinamakan pendidikan, yaitu sebuah kegiatan perbaikan tata laku dan pendewasaan manusia melalui pengetahuan. 
Kesadaran akan perlunya belajar sejak usia dini ini tidak muncul dari si bayi yang belum bisa apa-apa, akan tetapi dimulai dari kesadaran orang tua untuk memberikan penuntun pembelajaran kepada anak mereka sejak dini. Karena pada dasarnya ketika seorang manusia telah terlahir ke dunia ini, ia sudah dilengkapi berbagai perangkat seperti: panca indera dan akal budi untuk menyerap berbagai ilmu.

Inilah pelatak dasar pentingnya pendidikan usia dini; Dan sejak dini anak harus diajarkan berbagai ilmu (dalam bentuk rangsangan/stimulan). Mendidik anak pada usia dini ibarat membentuk ukiran di batu yang tidak akan mudah hilang, dan bahkan akan membekas selamanya; artinya pendidikan pada anak usia dini akan sangat membekas hingga anak telah tumbuh dewasa.

Pendidikan pada usia dini adalah modal dasar bagi pendidikan anak selanjutnya, karena keberhassilan ini sangat berperan besar bagi keberhasilan anak dimasa-masa selanjutnya. Lalu; pendidikan yang bagaimanakah diperlukan?. Tentu saja pendidikan yang tidak sekedar mengejar target kurikulum, atau mengejar keinginan masyarakat atau orang tua murid, seperti kemampuan anak membaca, menulis, dan menghitung secara maksimal. Pertumbuhan dan perkembangan anak memiliki keterbatasan tertentu untuk menyerap materi di sekolah konvensional. Einstein kecil misalnya, adalah seorang anak dengan keterbatasan tertentu, sehingga ia harus dikeluarkan dari sekolah. Agar fenomena di drop out nya Einstein tidak terulang, maka saat ini mulai tumbuh pemikiran tentang sekolah alternatif yaitu homeschooling (sekolah rumah).

Rumah merupakan lingkungan terdekat dan tempat belajar yang paling baik buat anak. Di rumah anak bisa belajar selaras dengan keinginannya sendiri. Ia tidak perlu duduk menunggu bel berbunyi, tidak perlu harus bersaing dengan anak-anak lainnya, tidak perlu harus ketakutan menjawab salah di depan kelas, dan bisa langsung mendapat penghargaan atau pembetulan kalau membuat kesalahan. Di dalam rumah banyak sekali sarana dan prasarana yang bisa dipakai untuk pembelajaran anak. Biasanya anak dapat belajar banyak sekali memahami konsep tentang benda, warna, angka-angka dan termasuk dapat mengenal mengenai ciptaan-ciptaan Tuhan melalui berbagai macam bentuk yang nyata di alam ini. Biasanya anak dapat belajar banyak sekali memahami konsep tentang benda, warna, angkaangka dan termasuk dapat mengenal mengenai ciptaan-ciptaan Tuhan melalui berbagai macam mahluk hidup yang ada disekitar lingkungan rumah. 
Pakar pendidikan, Prof. Dr. Arief Rahman, mengungkapkan bahwa kelebihan homeschooling adalah proses belajar yang berdekatan dengan orang, dan seharusnya yang mengajar dalam proses tersebut memang orang tua, bukan guru yang memberikan private.

\section{Tujuan Homeschooling}

Banyak kalangan yang berpendapat bahwa metode homeschooling bisa menghambat potensi sosial anak. Biasanya, anak akan diasumsikan kurang bisa bergaul, kurang bisa belajar bersosialisasi, kurang bisa belajar menerima pendapat orang lain atau tidak bisa bekerja sama. Pendapat seperti itu jelas keliru, karena anak-anak tersebut justru diharapkan untuk belajar dan mempraktekkan bagaimana belajar bermasyarakat secara baik dan benar. Oleh karena itu merupakan kegiatan belajar dimanapun, kapanpun, dan dengan siapapun. Dengan demikian orang tualah yang paling menentukan keberhasilan homeschooling mengingat orang terdekat bagi si anak itu sendiri.

Peran orang tua sebagai pendidik pertama dan utama, tidak hanya dalam rangka mendidik anak-anaknya semata. Hal ini disebabkan, anak-anaknya berinteraksi dengan anak orang lain di lingkungannya. Anak membutuhkan teman untuk belajar bersosialisasi dan berlatih menjadi pemimpin. Kesadaran sebagai seorang yang peduli dengan kondisi masyrakatnya akan menumbuhkan rasa tanggung jawab untuk turut mendidik anak-anak lain sebagai generasi penerus umat. Sehingga orang tua tidak cukup mendidik anak sendiri, tetapi juga perlu mendidik anak-anak lain bersama orang tua lainnya yang ada di lingkungannya.

\section{LANDASAN TEORI}

Dalam praktek pembelajaran, ada beberapa dasar dan landasan yang yang menjadi acuan bagi orang tua untuk memulai dan mendidik anaknya dalam sistem pendidikan homeschooling. Adapun teori yang menjadi dasar acuannya yaitu menyangkut teori perkembangan anak, teori kecerdasan Ganda.

\section{Teori Perkembangan Anak}

Beberapa penulis yang memberikan pemahaman tentang teori perkembangan anak seperti: Jean piaget (1896-1980). Teorinya mengenai Perkembangan Kognitif Anak, membahas tentang muncul dan diperolehnya skema-skema bagaimana seseorang mempersepsi lingkungannya dalam tahapan-tahapan perkembangan. Teori ini berpendapat 
bahwa kita membangun kemampuan kognitif melalui tindakan yang termotivasi dengan sendirinya terhadap lingkungan. Piaget membagi skema yang digunakan anak untuk memahami dunianya melalui empat periode utama, yaitu: Periode Sensori (usia 0 - 2 tahun), Periode Pra-operasional (usia 2 - 7 tahun), Periode Operasional Konkrit (usia 7 - 11 tahun), dan Periode Operasional Formal (usia 11 tahun sampai dewasa).

Berbeda dengan Piaget ialah Lev Vygotsky (1896-1934), memfokuskan pada Perkembangan Berpikir dalam Diri Anak (intrinsik); Vygotsky menekankan bahwa perkembangan kognitif seorang anak sangat dipengaruhi oleh sosial dan budaya anak tersebut tinggal. Setiap budaya memberikan pengaruh pada pembentukan keyakinan, nilai, norma kesopanan serta metode dalam memecahkan masalah sebagai alat dalam beradaptasi scara intelektual. Budayalah yang mengajari anak untuk berfikir dan apa yang seharusnya dilakukan.

Sedangkan Erick Erickson pakar psikologi perkembangan, memfokuskan pada perkembangan psikologisial sejak kecil hingga dewasa dalam delapan tahap. Setiap orang akan melewati tahapan, dan setiap tahapan akan mendapatkan pengalaman positif dan negatif. Kepribadian yang sehat akan diperoleh apabila seseorang dapat melewati krisis dalam tugas yang penuh cinta kasih sehingga ia merasa aman. Pada masa usia dini banyak hal yang menarik dalam dirinya, sehingga akan menjadikan ia ingin selalu mencoba walaupun terkadang berbahaya. Pada tahap ini orang dewasa harus memberikan dukungannya; dan Erickson, mengingatkan pembatasan dan kritik yang berlebihan akan menyebabkan tumbuh rasa ragu terhadap kemampuan dirinya.

\section{Teori Kecerdasan Ganda}

Howard Gardner (1983), Psikolog Pendidikan asal Amerika yang terkenal dengan teori Kecerdasan Ganda, mengatakan kecerdasan intelektual hanyalah salah satu dari Sembilan (9) kecerdasan yang dimiliki seseorang. Kecerdasan Ganda yang dimaksud Gardner adalah: kecerdasan linguistik verbal, kecerdasan logika matematika, kecerdasan special visual, kecerdasan ritmik musik, kecerdasan kinestetik, kecerdasan inter-personal, kecerdasan intra-personal, dan kecerdasan natural. Gardner mengingatkan kita bahwa anak-anak memiliki kemampuan yang berbeda-beda sesuai dengan bakat dan minatnya. Disamping it Gardner juga menegaskan bahwa: satu-satunya sumbangan paling penting untuk perkembangan anak adalah membantu untuk menemukan bidang yang paling cocok dengan 
bakatnya, yang akan membuatnya puas dan kompeten (Daniel Goleman: 2002:49). Sumbangan paling penting tersebut adalah dari pendidikan.

\section{PEMBAHASAN}

Istilah homeschooling sendiri berasal dari bahasa Inggris yang berarti sekolah rumah. Homeschooling berakar dan bertumbuh di Amerika Serikat; selain itu homeschooling disebut juga dengan home education, home based learning, atau sekolah mandiri. Pengertian umum homeschooling adalah: model pendidikan, dimana sebuah keluarga yang bertanggung jawab atas pendidikan anaknya dengan menggunakan rumah sebagai basis pendidikannya.

Memilih untuk bertanggung jawab berarti orang tua harus terlibat langsung dalam menentukan proses penyelenggaraan pendidikan, penentuan arah dan tujuan pendidikan, nilai-nilai yang hendak dikembangkan, kecerdasan dan ketrampilan, kurikulum dan materi, serta metode dan praktek belajar (Sumardiono, 2007:4).

Pendidikan anak usia dini adalah jenjang pendidikan sebelum melangkah kependidikan dasar yang merupakan suatu upaya pembinaan yang ditujukan bagi anak sejak lahir sampai dengan usia enam (6) tahun yang dilakukan melalui pemberian rangsangan pendidikan untuk membantu pertumbuhan dan perkembangan jasmani dan rohani agar anak memiliki kesiapan dalam memasuki pendidikan lebih lanjut, yang diselenggarakan pada jalur formal dan non formal.

Pendidikan anak usia dini merupakan salah satu bentuk penyelenggaraan pendidikan yang menitik beratkan pada peletakan dasar ke arah pertumbuhan dan perkembangan fisik (kordinasi motorik halus dan kasar), kecerdasan (daya pikir, kecerdasan emosi, kecerdasan spiritual), sosio emosional (sikap dan perilaku serta agama) bahasa dan komunikasi, sesuai dengan keunikan dan tahap-tahap perkembangan yang dilalui oleh anak tersebut.

Montessori salah seorang tokoh pendidikan mengatakan ketika mendidik anak-anak, kita hendaknya ingat bahwa mereka adalah individu-individu yang unik dan akan berkembang sesuai dengan kemampuan mereka sendiri. Tugas orang tua sebagai pendidik untuk memberikan sarana dorongan belajar dan memfasilitasinya ketika mereka telah siap untuk mempelajari sesuatu hal. Tahun-tahun pertama kehidupan anak merupakan masa-masa yang sangat baik untuk suatu pembentukan. Masa ini pula sebagai yang terpenting dalam perkembangan anak, baik secara fisik, mental maupun spiritual. Didalam keluarga dan pendidikan demokratis orang tua dan pendidik berusaha memfasilitasi pertumbuhan dan perkembangan yang dibutuhkan oleh anak. Olek karena itu, baik dan tepat bagi setiap orang 
tua dan pendidik yang terlibat pada proses pembentukan itu, mengetahui, memahami perkembangan anak usia dini.

Pemikiran Montessori tersebut mendapat dukungan dari tokoh pendidikan Taman Siswa, Ki Hadjar Dewantara yaitu sangat meyakinkan bahwa suasana pendidikan yang baik dan tepat adalah dalam suasana kekeluargaan, dan dengan prinsip "asih (mengasihi)", "asah (memahirkan)", “asuh (membimbing)". Anak tumbuh kembang dengan baik jika mendapatkan perlakuan kasih sayang, pengasuhan yang penuh pengertian dan dalam situasi yang damai dan harmonis. Ki Hadjar Dewantara menganjurkan agar dalam pendidikan, anak memperoleh pendidikan untuk "mencerdaskan (mengembangkan) pikiran”, pendidikan untuk "mencerdaskan hati (kepekaan hati nurani)", dan pendidikan yang "meningkatkan ketrampilan".

Kedua tokoh pendidikan di atas sangat menekankan bahwa untuk usia dini bahkan juga untuk mereka yang dewasa, kegiatan pembelajaran dan pendidikan itu bagaikan kegiatan-kegiatan yang disengaja namun sekaligus alamiah seperti bermain di taman. Bagaikan keluarga yang sedang mengasuh dan membimbing anak-anak secara alamiah sesuai kodrat anak di sebuah taman. Anak-anak yang mengalami suasana kekeluargaan yang hangat, akrab, damai, baik di rumah maupun di sekolah, serta mendapatkan bimbingan dengan penuh kasih saying, pelatihan kebiasaan secara alami, akan berkembang menjadi anak yang bahagia dan sehat. Hal tersebut sama seperti metode homeschooling pada umumnya.

Kiat bagaimana baiknya untuk mengetahui model homeschooling dalam pembelajaran terhadap anak usia dini sebagai berikut:

\section{Memulai Homeschooling}

Di dalam sistem pendidikan di Indonesia, keberadaan homeschooling adalah legal, memiliki dasar hukum yang jelas didalam UUD 1945 Pasal 31. Ayat (1) dan Ayat (2) maupun didalam UU No. 20 tahun 2003 Pasal 4, Pasal 5, dan Pasal 27 tentang Sistem Pendidikan Nasional. Ayat (1) menyebutkan bahwa kegiatan pendidikan informal yang dilakukan oleh keluarga dan lingkungan berbentuk kegiatan belajar secara mandiri. Sedangkan Ayat (2) menyebutkan bahwa sekolah rumah pada dasarnya dapat dibedakan menjadi dua, yaitu: a. Sekolah Rumah Tunggal merupakan layanan pendidikan yang dilakukan oleh orang tua/wali terhadap seorang anak atau lebih, terutama di rumahnya sendiri atau di tempat-tempat lain yang menyenangkan bagi peserta didik. b. Sekolah Rumah Majemuk merupakan layanan pendidikan yang dilakukan oleh orang tua/wali terhadap anak- 
anak dari satu lingkungan yang tidak selalu bertalian dalam keluarga, yang diselenggarakan di beberapa rumah atau tempat/fasilitas pendidikan yang ditentukan oleh suatu komunitas pendidikan yang dibentuk atau dikelola secara lebih teratur dan terstruktur.

Homeschooling adalah sebuah proses yang dapat dilakukan oleh orang tua manapun yang mencintai dan berdedikasi pada putra-putrinya. Apapun latar belakang pendidikan atau pekerjaan orang tua, tidak menghalangi orang tua untuk melakukan homeschooling. Yang diperlukan adalah komitmen, kesediaan belajar, dan bekerja keras. Homeschooling memang bukan sebuah hal yang mudah, tetapi dapat dijalankan karena sudah jutaan orang tua yang mempraktekkannya.

Proses pendidikan pada anak usia dini adalah sebuah pengalaman yang menarik bagi seluruh anggota keluarga. Didalam proses homeschooling, kita dapat terus belajar, membuka diri, dan maju bersama perkembangan anak-anak. Dengan segala dinamika yang terjadi pada anak-anak dan proses yang dialami bersama selama homeschooling, sikap bijaksana sebagai orang tua adalah mencari keseimbangan antara keteguhan keyakinan (determination) dan keterbukaan (open mindedness) didalam menjalankan homeschooling bagi anak-anak.

\section{Memahami Karakteristik Anak Usia Dini}

Bagi orang tua, untuk dapat memahami karakteristik anak dapat dilakukan dengan jalan: (1) Mengetahui hal-hal yang bermanfaat bagi perkembangan anak; (2) Mengetahui tugas-tugas perkembangan anak, sehingga dapat memberikan stimulasi kepada anak; (3) Mengetahui bagaimana membimbing proses belajar anak pada saat yang tepat sesuai dengan kebutuhannya (4) Menaruh harapan dan tuntutan anak secara realistis; dan (5) Mampu mengembangkan potensi anak secara optimal sesuai dengan keadaan dan kemampuannya.

Kelebihan di dalam homeschooling diantara: (1) Customized, sesuai kebutuhan anak dan kondisi keluarga; (2) Lebih memberikan peluang untuk kemandirian dan kreativitas individual; (3) Memaksimalkan potensi anak sejak usia dini, tanpa harus mengikuti standar waktu yang ditetapkan di sekolah; (4) Lebih siap untuk terjun di dunia nyata; (5) Kesesuaian pertumbuhan nilai-nilai anak dengan keluarga; (6) Relatif terlindung dari nilai pergaulan yang menyimpang; dan (7) Kemampuan bergaul dengan orang yang berbeda umur.

\section{Model Homeschooling untuk Anak Usia Dini}

Model pembelajaran di sekolah sampai saat ini masih juga seperti menghafal atau memasukkan informasi, dikhawatirkan tidak dapat mengembangkan potensi anak. Informasi 
yang dipelajari di sekolah dapat segera usang dan kehilangan relevansinya dengan dunia nyata. Untuk permasalahan tersebut, sudah seharusnya orang tua mengajarkan kepada anakanak untuk belajar mencari informasi yang diperlukan untuk proses pembelajaran (learn how to learn). Para guru dan orang tua murid perlu menyadari bahwa mereka bukan satu-satunya sumber pengetahuan dan informasi buat anak-anak.

Secara sadar, model pembelajaran yang harus dibangun adalah membangkitkan keingintahuan (curiosity). Ketrampilan bertanya dan mencari tahu adalah sebuah modal berharga yang perlu ditumbuhkan terus menerus selama perkembangan anak tersebut. Alihalih berpretensi sebagai orang tua super yang mampu menjawab semua pertanyaan, kita mengenalkan sumber-sumber informasi yang dapat membantu mereka menemukan jawaban atas pertanyaannya.

Keluarga yang menerapkan homeschooling harus bisa melihat bahwa model pembelajaran ini memiliki peluang yang besar untuk mengajarkan kebiasaan mencari informasi mandiri. Para orang tua homeschooling perlu memfokuskan arah pendidikan anakanaknya pada ketrampilan yang sarat dengan informasi terkini.

Mengajarkan anak-anak mencari informasi yang mereka perlukan adalah kekhawatiran yang seringkali muncul dari kemampuan orang tua homeschooling untuk mengajar anak mereka. Sebab orang tua homeschooling bukanlah guru (pengajar) dari seluruh materi pengajaran bagi anak-anaknya. Orang tua homeschooling lebih merupakan mentor yang membantu anak menunjukkan peta jalan (road map) masa depannya.

Pada dasarnya homeschooling bersifat unik; karena setiap keluarga mempunyai nilai dan latar belakang masalah yang berbeda. Setiap keluarga akan melahirkan pilihan-pilihan model homeschooling yang beragam bentuk, sesuai metode pendidikan yang diterapkan dengan kesukaan si anak itu sendiri.

Metode homeschooling sangat beragam bentuknya, mulai yang sangat tidak terstruktur (unschooling) sampai model yang sangat terstruktur (school at home). Dalam unschooling anak-anak dibiarkan belajar sesuai dengan minat mereka dan orang tua hanya memfasilitasinya. Sedangkan school at-home biasanya belajar seperti pada bentuk sekolah regular dengan menggunakan buku acuan (materi pembelajaran), hanya saja belajarnya di rumah.

Diantara dua (2) metode tersebut, ada banyak sekali metode belajar yang dapat diterapkan dalam homeschooling misalnya metode belajar cara Montessori yang mendorong 
orang tua terus menumbuh kembangkan keadaan lingkungan sehingga dapat mengembangkan potensinya baik secara fisik, mental, maupun spiritual. Metode unit studi yang mempelajari banyak mata pelajaran sekaligus dalam satu tema sehingga antara tiap-tiap mata pelajaran terdapat hubungan yang saling berkaitan. Metode living books yang mengajarkan suatu hal berdasarkan dunia nyata, dan beberapa metode belajar dalam penerapan homeschooling lainnya sperti metode klasik, Waldorf, dan Eclectic, pada dasarnya mengajak anak-anak untuk berinteraksi antara ilmu pengetahuan dengan dunia nyata dan penerapannya.

Metode-metode di atas akan lebih baik lagi apabila penerapannya anak-anak diajak berinteraksi dalam kehidupan sosial dengan membentuk sebuah group. Menjadi guru homeschooling, tidaklah berarti mendidik anak secara individual, namun dapat dilakukan secara berkelompok dengan melibatkan para orang tua yang ada disekitar lingkungannya. Sistem kelompok belajar dalam grup, selain menumbuhkan kebersamaan dan melatih anak dalam bersosialisasi juga menyuburkan persaudaraan dan kedekatan diantara orang tua sehingga memudahkan memberikan penyelesaian terhadap permasalahan-permasalahan yang muncul dari dalam anak-anak tersebut. Dengan demikian anak-anak usia dini mendapatkan pelajaran dalam bentuk kelompok dan akan melanjutkan pelajaran mereka di rumah bersama orang tua masing-masing.

\section{SIMPULAN}

Pendidikan anak usia dini merupakan bentuk pendidikan yang sangat mendasar dan strategis sebgai suatu proses dalam pembangunan sumber daya manusia, karena menitikberatkan pada peletakan dasar kearah pertumbuhan dan perkembangan fisik, kecerdasan, sosial, emosional, serta bahasa komunikasi sesuai dengan keunikan dan tahaptahap perkembangan yang dilalui oleh anak yang bersangkutan. Oleh karena itu, model homeschooling bagi orang tua sangat diperlukan dan dapat dilaksanakan untuk mencapai keberhasilan anak. Metode homeschooling bisa menjadi alternatif untuk pendidikan anak usia dini; selain penerapannya dilakasanakan di lingkungan rumah, anak dapat langsung berinteraksi dan menerapkan pengetahuannya di dunia nyata, disamping itu pula si anak bisa langsung mendapat penjelasan atau pembetulan saat membuat kesalahan.

Dengan demikian untuk dapat melaksanakan kegiatan metode homeschooling, orang tua harus bisa meluangkan dan menyediakan waktu untuk putra-putrinya serta bersikap 
kreatif dan inovatif agar mampun menarik minat dan berinteraksi dalam mengetahui keingintahuan anak yang bersangkutan.

\section{DAFTAR PUSTAKA}

Kiyosaki, Robert T. 2011. Sekolah Rumah : Pendidikan Berbasis Keluarga. http://www.sekolahrumah.com. Diakses 15 Mei 2011

Qnoyzone.blogdetik. 2009. Fenomena Homeschooling di Indonesia. http://karpetbasah.blogspot.com/2009/03/fenomena-homeschooling-di-indonesia.html. diakses 15 Mei 2011

Riyanto,dkk. 2004. Pendidikan Pada Usia Dini. Jakarta: Grasindo.

Simbolon, Pormadi. 2007. Home schooling : Sebuah Pendidikan Alternative. http://pormadi.wordpress.com/2007/11/12/homeschooling. diakses 23 Mei 2011

Sumardiono. 2007. Homeschooling, Lompatan Cara Belajar. Jakarta: PT. Elex Media Komputindo.

Sunarto, dkk. 2006. Perkembangan Peserta Didik. Jakarta: Reneka Cipta.

Wordpress. 2010. Pembelajaran Guru : Berbagai Bahan Terkait Model-Model pembelajaran.http://pembelajaranguru.wordpress.com. diakses 20 Mei 2011 